\title{
Character Association for Yield and its Components in Black Gram [Vigna mungo (L.) Hepper]
}

\author{
M.P. Arya Gopinath*, S.S. Desai, M.G. Palshetkar, \\ Hawaldhar Ayyajahamad Harun and V.A. Raje Mahadik
}

Department of Agriculture Botany, College of Agriculture, Dr.B.S.K.K.V. Dapoli, Dapolitaluk, Ratnagiri District, Maharashtra State, Pin: 415712, India

*Corresponding author

\section{A B S T R A C T}

Keywords

Black gram,

Correlation, Seed

yield, Phenotypic

level, Genotypic

level.

Article Info

Accepted:

26 June 2018

Available Online:

10 July 2018
The experiment was conducted at Research and Education Farm, Department of Agril. Botany, College of Agriculture, Dapoli, Dist. Ratnagiri, Maharashtra state, India during rabi 2017-2018.64 germplasms were evaluated through 13 traits like days to 50 per cent flowering, days to maturity, plant height, number of primary branches per plant, number of clusters per plant, number of pods per cluster, number of pods per plant, pod length, number of seeds per pod, 100 seed weight, harvest index, protein content and seed yield per plant. Relationship between physiological characters and yield contributing attributes was studied through analysis of correlation. Association studies revealed that, seed yield per plant was positively and significantly correlated with plant height, number of clusters per plant, number of pods per cluster number of pods per plant, pod length and protein content at both phenotypic and genotypic level, level indicating that these six traits could be important for improving the seed yield in black gram.

\section{Introduction}

Black gram (Vignamungo (L.) Hepper) is an important pulse crop of India. It is a short duration and self-pollinated grain legume utilized in the food, fodder, soil conservation, integrated farming systems, reclaiming of degraded pastures and symbiotic nitrogen fixation grown in many parts of India. This crop is grown in cropping systems as a mixed crop, catch crop, sequential crop besides growing as sole crop under residual moisture conditions after the harvest of rice and also before and after the harvest of other summer crops under semi irrigated and dry land conditions. Presently it is cultivated in India, Pakistan, Bangladesh, Myanmar, Thailand, Philippines, China and Indonesia (Poehlman 1991). Its seeds are highly nutritious with protein $(25-26 \%)$, carbohydrates $(60 \%)$, fat (1.5\%), minerals, amino acids and vitamins (Anon., 2016). Yield is a complex trait determined by several component traits, therefore identifying the characters which are closely related and have contributed to yield becomes highly essential. The estimates of correlation coefficients mostly indicate the inter-relationships of the characters. So the 
knowledge of correlation between yield and its component traits is essential for seed yield improvement through selection programs. So this research effort is undertaken to ascertain the association between seed yield and its related components among sixty four different black gram genotypes for evolving the superior high yielding ones.

\section{Materials and Methods}

The present investigation was conducted at Research and Education Farm, Department of Agril. Botany, College of Agriculture, Dapoli, Dist. Ratnagiri, Maharashtra state with 64 genotypes of black gram during rabi season, 2017-18. The experiment was laid out in randomized block design with three replications. Each genotype was grown in a plot of three rows of $2.4 \mathrm{~m}$ length each with inter-row spacing of $30 \mathrm{~cm}$. All recommended management practices were followed during the crop period. Observations were recorded on days to 50 per cent flowering, days to maturity, plant height $(\mathrm{cm})$, number of primary branches per plant, number of clusters per plant, number of pods per cluster, number pods per plant,100 seed weight (g), harvest index (\%), protein content (\%) and seed yield per plant $(\mathrm{g})$. The phenotypic and genotypic correlation coefficients were calculated from phenotypic and genotypic variances and covariances. The genotypic and phenotypic covariances were worked out as per the formulae given by Singh and Chaudhary (1977).

\section{Results and Discussion}

The results (Table 1 and 2) showed that the genotypic correlations of seed yield were higher than phenotypic ones with majority of the characters studied. This indicates relatively low influence of environment in modifying the total expression of the genotypes, thus altering the phenotypic expression. Plants that produce more clusters per plant produce more number of pods per plant along with more number of seeds per pod are desirable. In the present study, seed yield per plant was positively and significantly correlated with plant height, number of clusters per plant, number of pods per cluster number of pods per plant, pod length and protein content at both phenotypic and genotypic level, level indicating that these six traits could be important for improving the seed yield in black gram. Similar kind of positive significant association of seed yield with different quantitative traits were reported earlier by Shivade et al., (2011); Pushpa et al., (2013); Jyothsna et al., (2016). The number of pods per plant can be increased by increasing number of primary branches per plant owing to a strong significant positive correlation between them. Strong positive association between number of clusters per plant and number of pods per cluster with number of pods per plant suggested that prime importance should be given to these characters for maximising yield. Selection for longer pods may reward due to the highly significant association of pod length with number of seeds per pod. Longer pods with more number of seeds may enhance the seed yield, thus break the yield plateau. Non-significant correlation of seed yield 100 seed weight indicated that bold seeded genotypes are not much desirable for achieving higher seed yield in black gram.

It is concluded that the seed yield is highly complex trait, thus indirect selection based on major component traits may increase the efficiency of breeder. The present investigation has indicated the importance of plant height, number of clusters per plant, number of pods per cluster, number of pods per plant, pod length and number of seeds per pod which are important traits for improving the yield. Therefore, due emphasis should be given to these traits in the selection programme to evolve high yielding genotypes in black gram. 
Table.1 Estimates of phenotypic correlation coefficient between different characters in Black gram

\begin{tabular}{|c|c|c|c|c|c|c|c|c|c|c|c|c|c|}
\hline Sr. no. & $\begin{array}{l}\text { Days to } 50 \% \\
\text { flowering }\end{array}$ & $\begin{array}{l}\text { Days to } \\
\text { maturity }\end{array}$ & $\begin{array}{l}\text { Plant height } \\
\quad(\mathrm{cm})\end{array}$ & $\begin{array}{l}\text { Number of } \\
\text { primary } \\
\text { branches per } \\
\text { plant }\end{array}$ & $\begin{array}{c}\text { Number of } \\
\text { clusters per } \\
\text { plant }\end{array}$ & $\begin{array}{l}\text { Number of } \\
\text { pods per } \\
\text { cluster }\end{array}$ & $\begin{array}{l}\text { Number } \\
\text { of pods per } \\
\text { plant }\end{array}$ & $\begin{array}{l}\text { Pod length } \\
\quad(\mathrm{cm})\end{array}$ & $\begin{array}{c}\text { Number of } \\
\text { seeds per } \\
\text { pod }\end{array}$ & $\begin{array}{l}100 \text { seed weight } \\
(\mathrm{g})\end{array}$ & $\begin{array}{l}\text { Harvest } \\
\text { index } \\
(\%)\end{array}$ & $\begin{array}{l}\text { Protein } \\
\text { content } \\
(\%)\end{array}$ & $\begin{array}{l}\text { Seed yield per } \\
\text { Plant } \\
(\mathrm{g})\end{array}$ \\
\hline $\begin{array}{l}\text { Days to } 50 \% \\
\text { flowering }\end{array}$ & 1.0000 & $0.9814 * *$ & $0.4188 * *$ & 0.0265 & 0.0556 & 0.0650 & 0.0579 & 0.1157 & -0.0670 & $0.2369 * *$ & 0.1139 & -0.0396 & 0.1276 \\
\hline $\begin{array}{l}\text { Days to } \\
\text { maturity }\end{array}$ & & 1.0000 & $0.3756 * *$ & 0.0045 & 0.0521 & 0.0524 & 0.0551 & 0.1181 & -0.0536 & $0.1803 *$ & 0.1166 & -0.0614 & 0.1120 \\
\hline $\begin{array}{c}\text { Plant } \\
\text { height }(\mathrm{cm})\end{array}$ & & & 1.0000 & $0.1477 *$ & $0.2396 * *$ & $0.1532 *$ & $0.2720 * *$ & 0.1024 & -0.0881 & $0.3864 * *$ & 0.0332 & 0.0405 & $0.3235 * *$ \\
\hline $\begin{array}{l}\text { Number of } \\
\text { primary } \\
\text { branches per } \\
\text { plant }\end{array}$ & & & & 1.0000 & -0.0775 & $0.2464 * *$ & 0.0252 & $0.1799 *$ & -0.0856 & $0.1490 *$ & -0.0094 & 0.0697 & 0.0088 \\
\hline $\begin{array}{l}\text { Number of } \\
\text { clusters per } \\
\text { plant }\end{array}$ & & & & & 1.0000 & 0.1300 & $0.7804 * *$ & 0.0623 & $0.1740 *$ & $-0.1550 *$ & 0.0861 & 0.0807 & $0.6817 * *$ \\
\hline $\begin{array}{l}\text { Number of } \\
\text { pods per } \\
\text { cluster }\end{array}$ & & & & & & 1.0000 & $0.6168 * *$ & $0.1812 *$ & 0.1114 & 0.0461 & -0.0877 & 0.0432 & $0.6285 * *$ \\
\hline $\begin{array}{c}\text { Number of } \\
\text { pods per plant }\end{array}$ & & & & & & & 1.0000 & 0.1296 & $0.1994 * *$ & -0.0896 & 0.0360 & 0.0611 & $0.9042 * *$ \\
\hline $\begin{array}{l}\text { Pod length } \\
\text { (cm) }\end{array}$ & & & & & & & & 1.0000 & $0.5023 * *$ & 0.0080 & 0.0675 & $0.3824 * *$ & $0.2962 * *$ \\
\hline $\begin{array}{l}\text { Number of } \\
\text { seeds per pod }\end{array}$ & & & & & & & & & 1.0000 & $-0.4240 * *$ & $0.1745^{*}$ & $0.3010 * *$ & $0.3458 * *$ \\
\hline $\begin{array}{l}100 \text { seed } \\
\text { weight }(\mathrm{g})\end{array}$ & & & & & & & & & & 1.0000 & -0.1389 & 0.0155 & 0.1083 \\
\hline $\begin{array}{l}\text { Harvest index } \\
(\%)\end{array}$ & & & & & & & & & & & 1.0000 & -0.0185 & 0.0716 \\
\hline $\begin{array}{c}\text { Protein } \\
\text { content }(\%)\end{array}$ & & & & & & & & & & & & 1.0000 & $0.1786^{*}$ \\
\hline
\end{tabular}


Table.2 Estimates of genotypic correlation coefficient between different characters in Black gram

\begin{tabular}{|c|c|c|c|c|c|c|c|c|c|c|c|c|c|}
\hline Sr. no. & $\begin{array}{c}\text { Days to } \\
50 \% \\
\text { flowering }\end{array}$ & $\begin{array}{l}\text { Days to } \\
\text { maturity }\end{array}$ & $\begin{array}{c}\text { Plant } \\
\text { height }(\mathrm{cm})\end{array}$ & $\begin{array}{l}\text { Numberof } \\
\text { primary } \\
\text { branches } \\
\text { per plant }\end{array}$ & $\begin{array}{l}\text { Number } \\
\text { of clusters } \\
\text { per plant }\end{array}$ & $\begin{array}{l}\text { Number of } \\
\text { pods per } \\
\text { cluster }\end{array}$ & $\begin{array}{c}\text { Number of } \\
\text { pods per } \\
\text { plant }\end{array}$ & $\begin{array}{l}\text { Pod length } \\
\quad(\mathrm{cm})\end{array}$ & $\begin{array}{c}\text { Number of } \\
\text { seeds per pod }\end{array}$ & $\begin{array}{c}100 \text { seed } \\
\text { weight }(\mathrm{g})\end{array}$ & $\begin{array}{l}\text { Harvest } \\
\text { index }(\%)\end{array}$ & $\begin{array}{c}\text { Protein } \\
\text { content }(\%)\end{array}$ & $\begin{array}{l}\text { Seed yield } \\
\text { per } \\
\text { Plant }(\mathrm{g})\end{array}$ \\
\hline $\begin{array}{c}\text { Days to } \\
50 \% \\
\text { flowering }\end{array}$ & 1.0000 & $0.9896 * *$ & $0.4999 * *$ & 0.0550 & 0.0935 & 0.1291 & 0.1101 & 0.1198 & -0.0847 & $0.2501 * *$ & 0.1362 & -0.0427 & 0.1738* \\
\hline $\begin{array}{l}\text { Days to } \\
\text { maturity }\end{array}$ & & 1.0000 & $0.4489 * *$ & 0.0256 & 0.0883 & 0.1094 & 0.1051 & 0.1211 & -0.0684 & $0.1933 * *$ & 0.1357 & -0.0670 & 0.1548* \\
\hline $\begin{array}{c}\text { Plant } \\
\text { height }(\mathrm{cm})\end{array}$ & & & 1.0000 & 0.1092 & $0.2864 * *$ & 0.1353 & $0.2906 * *$ & 0.1217 & -0.1005 & $0.4321 * *$ & 0.0319 & 0.0876 & $0.3527 * *$ \\
\hline $\begin{array}{l}\text { Number of } \\
\text { primary } \\
\text { branches } \\
\text { per plant }\end{array}$ & & & & 1.0000 & -0.1215 & $0.2548 * *$ & -0.0296 & $0.2037 * *$ & -0.0840 & $0.1704 *$ & -0.0132 & 0.1210 & -0.0331 \\
\hline $\begin{array}{l}\text { Number of } \\
\text { clusters per } \\
\text { plant }\end{array}$ & & & & & 1.0000 & $0.1867 * *$ & $0.8068 * *$ & 0.0736 & $0.2330 * *$ & $-0.1794 *$ & 0.1412 & 0.0885 & $0.6741 * *$ \\
\hline $\begin{array}{l}\text { Number of } \\
\text { pods per } \\
\text { cluster }\end{array}$ & & & & & & 1.0000 & $0.6768 * *$ & $0.2053 * *$ & $0.2141 * *$ & 0.0529 & -0.1206 & 0.0870 & $0.7017 * *$ \\
\hline $\begin{array}{l}\text { Number of } \\
\text { pods per } \\
\text { plant }\end{array}$ & & & & & & & 1.0000 & $0.1431 *$ & $0.2781 * *$ & -0.1033 & 0.0633 & 0.0839 & $0.9035 * *$ \\
\hline $\begin{array}{l}\text { Pod length } \\
\quad(\mathrm{cm})\end{array}$ & & & & & & & & 1.0000 & $0.5758 * *$ & 0.0082 & 0.0843 & $0.4063 * *$ & $0.3259 * *$ \\
\hline $\begin{array}{l}\text { Number of } \\
\text { seeds per } \\
\text { pod }\end{array}$ & & & & & & & & & 1.0000 & $-0.4712 * *$ & $0.1941 * *$ & $0.3447 * *$ & $0.4196 * *$ \\
\hline $\begin{array}{c}100 \text { seed } \\
\text { weight }(\mathrm{g})\end{array}$ & & & & & & & & & & 1.0000 & $-0.1472 *$ & 0.0151 & 0.1172 \\
\hline $\begin{array}{l}\text { Harvest } \\
\text { index (\%) }\end{array}$ & & & & & & & & & & & 1.0000 & -0.0126 & 0.1005 \\
\hline $\begin{array}{c}\text { Protein } \\
\text { content }(\%)\end{array}$ & & & & & & & & & & & & 1.0000 & $0.2157 * *$ \\
\hline
\end{tabular}




\section{Acknowledgements}

Necessary facilities provided by Department of Agril. Botany are acknowledged. Authors express their gratitude to Head of the department of Botany Dr. B.L. ThawareSir and Dr. V.V. Dalvi (Associate Professor) for their valuable guidance and support.

\section{References}

Anonymous (2016). http://iipr.res.in Jyothsna, T.S., Patro, S.K., Ashok, S., Sandhya rani, Y. and Neeraja, B. (2016).Character association and path analysis of seed yield and its yield components in black gram (Vigna mungo (L.) Hepper). International journal of theoretical \& applied sciences, 8(1): 12-16.

Poehlman, J.M. (1991). The mungbean.
Oxford and IBH Publishing Co., New Delhi, India.

Pushpa, R.Y., Koteswara Rao, Y., Satish, Y. and Sateesh Babu, J. (2013). Estimates of genetic parameters and path analysis in black gram (Vigna mungo (L.) Hepper). International Journal of Plant, Animal and Environmental Sciences. Vol3: 4.

Shivade, H.A., Rewale and Patil S.B. (2011). Correlation and path analysis for yield and yield components in black gram (Vigna mungo (L.) Hepper). Legume Research, 34 (3): 178 - 183.

Singh, R.K. and Choudhary (1977). Biometrical method in quantitative genetics and plant breeding experimental techniques (first Ed.), Kalyani Publication, New Delhi. pp. 220-223.

\section{How to cite this article:}

Arya Gopinath, M.P., Desai, S.S., Palshetkar, M.G., Hawaldhar Ayyajahamad Harun and Raje Mahadik, V.A. 2018. Character Association for Yield and its Components in Black Gram [Vigna mungo (L.) Hepper]. Int.J.Curr.Microbiol.App.Sci. 7(07): 3964-3968.

doi: https://doi.org/10.20546/ijcmas.2018.707.461 